\title{
Antigen Absorption in Bacterial Diarrhea: In Vivo Intestinal Transport of $\beta$-Lactoglobulin in Rabbits Infected with the Entero-Adherent Escherichia coli Strain RDEC-1
}

\author{
MARTIN GOTTELAND, ERIKA ISOLAURI, MARTINE HEYMAN, DANIEL TOME, AND JEHAN- \\ FRANÇOIS DESJEUX
}

INSERM U.290, Hôpital Saint-Lazare, Paris, France

\begin{abstract}
We studied the absorption of both antigenic and degraded $\beta$-lactoglobulin ( $\beta$-LG) from the ileum to the portal blood, in rabbits infected at weaning with the enteroadherent Escherichia coli strain RDEC-1. The infection was characterized by high bacterial excretion from days 7 to 18 postinfection (pi), acute diarrhea for 10 days, and considerable growth retardation. Intestinal absorption of $\beta$-LG was measured at four stages of the infection: early (day 3 pi), peak (day 10 pi), late (day 18 pi), and recovery (day $30 \mathrm{pi}$ ). During the 30 -day period of infection, agematched control rabbits exhibited a significant decrease in antigenic and degraded $\beta$-LG absorption. In both control and infected animals, more than $90 \%$ of the $\beta$-LG was absorbed by a degrading pathway and the remainder in antigenic form by a minor pathway. RDEC-1 infection significantly raised antigenic $\beta$-LG absorption from days 10 to $30 \mathrm{pi}$, which delayed the decrease that normally occurs with age. Degraded $\beta$-LG absorption was not modified by the infection, except for a slight increase observed at the recovery stage (day $30 \mathrm{pi}$ ). These results suggest that RDEC-1 diarrhea increases absorption of food antigens. The subsequent local or systemic immune responses are not known, but pathologic consequences are possible in susceptible individuals. (Pediatr Res 26: 237-240, 1989)
\end{abstract}

Abbreviations

$\beta$-LG, $\beta$-lactoglobulin

pi, postinfection

EPEC, enteropathogenic $E$. coli

HRP, horseradish peroxidase

The possible influence of infectious diarrhea on subsequent food sensitization in infants is still under investigation. Different animal models of gastrointestinal infection have shown that some types of infection (e.g. by rotavirus) might increase intestinal permeability to antigens $(1,2)$, but others might not (e.g. cholera toxin-induced secretory diarrhea) (3). The intestinal endocytosis of antigenic food proteins is a physiologic process (4) which generally does not lead to pathologic immune responses. Using horseradish peroxidase, we previously observed (5) that protein absorption proceeded along two functional pathways: a minor pathway allowing the transport of the native protein $(10 \%$ of

Received January 24, 1989; accepted April 18, 1989.

Reprint requests Martin Gotteland, INSERM U.290, Hôpital Saint-Lazare, 107 bis, rue du Faubourg Saint-Denis, 75010 Paris, France. total protein transport), and a major pathway via which the remaining $90 \%$ is transported and which involves lysosomal degradation.

In our work, we studied the effects of diarrhea caused by EPEC on antigen absorption in young rabbits. EPEC strains are important causes of gastrointestinal diseases, and especially affect infants throughout the world (6); they do not produce heat-labile or heat-stable enterotoxins and are not entero-invasive. Some EPEC strains adhere closely to the enterocyte surface, and cause brush-border effacement. In 1977, Cantey and Blake (7) described RDEC-1, an EPEC strain specific to the newly weaned rabbit which closely reproduces lesions associated with EPEC infection in humans (8). Our aim in this study was to determine whether or not RDEC-1 infection modifies intact or degraded protein transport in the course of the disease. $\beta$-LG was used as the test food protein because it is known to be mainly responsible for cow's milk protein intolerance in human infants.

\section{MATERIALS AND METHODS}

Infection of Rabbits. The nalidixic acid resistant strain RDEC1 (015: NM), obtained from E. C. Boedeker (Walter Reed Army Institute of Research, Washington, DC), was grown in Penassaybroth (Difco Laboratories Inc., Detroit, MI) at $37^{\circ} \mathrm{C}$ for $18 \mathrm{~h}$ to promote pili adherence factor rabbit 1 . Bacteria were harvested by centrifugation at $2500 \times g$ for $10 \mathrm{~min}$, washed twice in sterile $\mathrm{PBS}$, and resuspended in saline at a concentration of $10^{8}$ bacteria/ $\mathrm{mL}$.

Freshly weaned male New Zealand White rabbits (Lessieux, Bray-Lu, France), aged 30-32 days and weighing 650-750 g, were inoculated intragastrically with $5 \mathrm{~mL}$ of $10 \% \mathrm{NaHCO}_{3}$ followed by $4 \mathrm{~mL}$ of the bacterial solution. The day of infection was taken as day 0 . The age-matched control animals were separated from the experimentally infected animals to avoid cross-contamination. Animals were given conventional food which was checked to be free of cow's milk proteins (UAR, Epinay sur Orge, France). Altogether, 23 infected and 22 control rabbits were studied. Rabbits were checked at days $0,3,7,10$, $14,18,24$, and 30 pi for wt, fecal excretion of bacteria, and diarrheal index; feces were weighed, homogenized in sterile saline, and serial dilutions were inoculated onto Mac-Conkey agar plates (Pasteur Production, Marne la Coquette, France) containing $50 \mu \mathrm{g} / \mathrm{mL}$ nalidixic acid (Sigma, La Verpillière, France). After overnight incubation, the number of colony forming units/ $\mathrm{mL}$ was determined. Diarrheal index was graded 0 when there was no diarrhea, 1 for soft stools, 2 for soft/liquid stools, and 3 for liquid stools.

Preparation of Radio-labeled $\beta-i G$. $\beta$-LG was labeled according to Jentoft and Dearborn (9): $100 \mathrm{mg}$ of $\beta$-LG (Sigma, $3 \times$ 
crystallized) in $50 \mathrm{~mL} 0.1 \mathrm{M}$ PBS, $\mathrm{pH} 7.4$, containing $0.1 \mathrm{M}$ $\mathrm{NaCNBH}_{3}$ was mixed with $0.5 \mathrm{mCi}\left[\mathrm{C}^{14}\right]$-formaldehyde (Amersham Corp., Arlington Heights, IL). The solution was incubated overnight at $4^{\circ} \mathrm{C}$, and the $\beta$-LG was then precipitated with $100 \%$ TCA (vol/vol), and pelleted for $30 \mathrm{~min}$ at $4000 \times \mathrm{g}$ and $4^{\circ} \mathrm{C}$. The pellet was redissolved in $0.1 \mathrm{M}$ PBS, pH 7.4 using $0.1 \mathrm{~N}$ $\mathrm{NaOH}$. After four more precipitations, the solution was dialyzed against distilled water and equilibrated with Ringer solution for five days. The $\beta$-LG concentration was determined by measuring the absorbance at $280 \mathrm{~nm}$. An aliquot of the solution was counted to determine the specific activity $(0.1 \mathrm{Ci} / \mathrm{mmol})$. The radiolabeled $\beta$-LG was then maintained at $-80^{\circ} \mathrm{C}$ until use.

In Vivo Measurement of $\beta-L G$ Intestinal Absorption. Surgical procedure. The intestinal absorption of $\beta-\mathrm{LG}$ was measured from a ligated ileal loop to the portal blood. Experiments were done on days $3,10,18$, and $30 \mathrm{pi}$, corresponding respectively to the early, peak, late, and recovery stages of the infection.

Control animals were individually tested before surgical procedure to check the absence of contamination. Rabbits were anaesthetized with an intravenous injection of sodium pentobarbital $(30 \mathrm{mg} / \mathrm{kg}$ body wt). After laparotomy, a $20-\mathrm{cm}$ long loop was gently washed with saline and prepared at the distal ileum level. The portal vein was then canulated using a PE 90 catheter connected to a $20-\mathrm{mL}$ syringe containing $50 \mathrm{U} / \mathrm{mL}$ heparinized Ringer solution. The catheter was introduced into the portal vein via the right branch and kept in position by ligatures. One $\mathrm{mL}$ of portal blood was removed as a background sample. A total of $10 \mathrm{~mL}$ of Ringer solution containing $5 \mathrm{mg} / \mathrm{mL} \beta-\mathrm{LG},\left[{ }^{14} \mathrm{C}\right] \beta-\mathrm{LG}$ $(0.3 \mu \mathrm{Ci} / \mathrm{mL})$, and $2 \mathrm{mg} / \mathrm{mL}$ PEG 4000 were introduced into the loop, and the abdomen was closed. One $\mathrm{mL}$ portal blood samples were collected for $4 \mathrm{~h}$ at 30-min intervals and replaced by $1.5 \mathrm{~mL}$ of heparinized Ringer solution. At the end of the experiment, the loop surface area was measured. In some experiments, the final $\beta$-LG concentration in the loop was determined by RP-HPLC to check the extent of possible intraluminal hydrolysis, using PEG 4000 as volume marker. Samples were injected in a water gradient system equipped with a $\mathrm{C} 18 \mu$ Bondapack column $(350 \times 4.6 \mathrm{~mm})$ and a UV detector at 214 $\mathrm{nm}$. The column was eluted at $40^{\circ} \mathrm{C}$ with a linear gradient of acetonitrile in $0.1 \%$ TFA at a flow rate of $2 \mathrm{~mL} / \mathrm{min}$.

Determination of $\beta-L G$ in plasma samples. Blood samples were maintained at $4^{\circ} \mathrm{C}$ and centrifuged for $10 \mathrm{~min}$ at $1500 \times \mathrm{g}$. The plasma was separated and $50 \mu \mathrm{L} /$ sample were immediately counted for ${ }^{14} \mathrm{C}$ using liquid scintillation spectrometry. The remainder was frozen at $-80^{\circ} \mathrm{C}$ until we performed the ELISA. The total quantity of $\beta$-LG in plasma samples was determined by measuring their $\left[{ }^{14} \mathrm{C}\right]$ radioactivity, assuming that the specific activity of the $\beta$-LG was unchanged during transport. This total quantity included both the antigenic and degraded forms of the protein. The fraction of $\beta$-I.G that had crossed the tissue in antigenic form was measured by ELISA. $\beta$-LG fluxes were defined as the amount of protein passing through the portal blood per intestinal surface unit are:!, as a function of time, expressed in $\mathrm{ng} / \mathrm{mL}$ plasma. $\mathrm{cm}^{2}$ loop su.face area. Degraded $\beta$-LG fluxes were subsequently calculated as total minus antigenic $\beta$-LG fluxes.

Immunoreactive $\beta$-LG was detected by the double sandwich ELISA. For this purpose, antisera were raised by subcutaneous injection of rabbits and rats with $3 \mathrm{mg} \beta-\mathrm{LG}$ in $0.5 \mathrm{~mL}$ saline solution emulsified with $0.5 \mathrm{~mL}$ Freund's complete adjuvant. Then 3 wk later, the same injections were repeated once daily, for 3 consecutive days. Five days after the final injection, the sera were tested, the animals bled, and sera were stored at $-80^{\circ} \mathrm{C}$ until use. Microtiter plates (Nunc, Polylabo, Paris, France) were then coated for $3 \mathrm{~h}$ at $37^{\circ} \mathrm{C}$ with $100 \mu \mathrm{L} /$ well of rabbit $\beta$-LG antiserum diluted $1: 100$ in $0.01 \mathrm{M}$ carbonate buffer $\mathrm{pH} 9.6$. Plates were washed with PBS-0.05\% Tween pH 7.4 and shaken dry. A total of $100 \mu \mathrm{L}$ of $1 \%$ gelatin (Prolabo, France) was added to each well and plates were stored overnight at $4^{\circ} \mathrm{C}$. Plates were then washed and $100 \mu \mathrm{L}$ of serial dilutions containing either the test sera or 0.01 to $200 \mathrm{ng}$ of $\beta$-LG in PBS-Tween were added in duplicate to each well and incubated for $1 \mathrm{~h}$ at $37^{\circ} \mathrm{C}$. After further washing of plates, $100 \mu \mathrm{L}$ of rat $\beta$-LG antiserum diluted $1: 1000$ in PBS-Tween was added and incubated for $1 \mathrm{~h}$ at $37^{\circ} \mathrm{C}$. Plates were again washed, and $100 \mu \mathrm{L}$ of $1: 3000$ goat antirat $\mathrm{IgG}$ peroxidase conjugate (Tebu, Le Perray, France) was added and left for $1 \mathrm{~h}$ at $37^{\circ} \mathrm{C}$. The preparation was then thoroughly washed and peroxidase assayed by staining with $0.4 \mathrm{mg} / \mathrm{mL}$ diamino orthophenylene in $0.05 \mathrm{M}$ citrate buffer $\mathrm{pH} 4.0$ containing $0.1 \%$ $\mathrm{H}_{2} \mathrm{O}_{2}$. The staining was developed in the dark with external stirring at room temperature for $25 \mathrm{~min}$. The reaction was stopped with $6 \mathrm{~N} \mathrm{H}_{2} \mathrm{SO}_{4}$ and absorbance measured at $492 \mathrm{~nm}$ with an Uniskan plate reader (Flow Laboratories, McLean, VA). The $\beta$-LG concentration in samples was determined using the standard curve; the detection limit was $1 \mathrm{ng} / \mathrm{mL}$.

Statistics. Statistical analyses were made using the SAS program (10). Logarithmic transformations were applied because of skewed distribution in the $\beta$-LG fluxes. ANOVA and Student's $t$-test were used to compare means and ranges.

\section{RESULTS}

Pathology. RDEC-1 infection was combined with high mortality and morbidity (20 and $70 \%$, respectively). As indicated in Figure $1 A$, the experimentally induced infection resulted in substantial growth retardation. In infected animals, the loss of wt reached $30 \% 1 \mathrm{mo}$ after bacterial inoculation compared to the age-matched controls. Although bacterial excretion was high as soon as day 3 pi (Fig. $1 B$ ), diarrhea only began at day 7 , peaked on day 10 and then gradually decreased during the 3 rd wk pi. By day 30 pi, both bacterial excretion and diarrhea had resolved.

Time-course of $\beta-L G$ fluxes from ileum to blood in control rabbits. The $\beta$-LG introduced into the ligated ileal loop reappeared in both antigenic and degraded form in portal blood samples. The absence of intraluminal hydrolysis was checked by HPLC analysis of the loop content at the end of the experiments
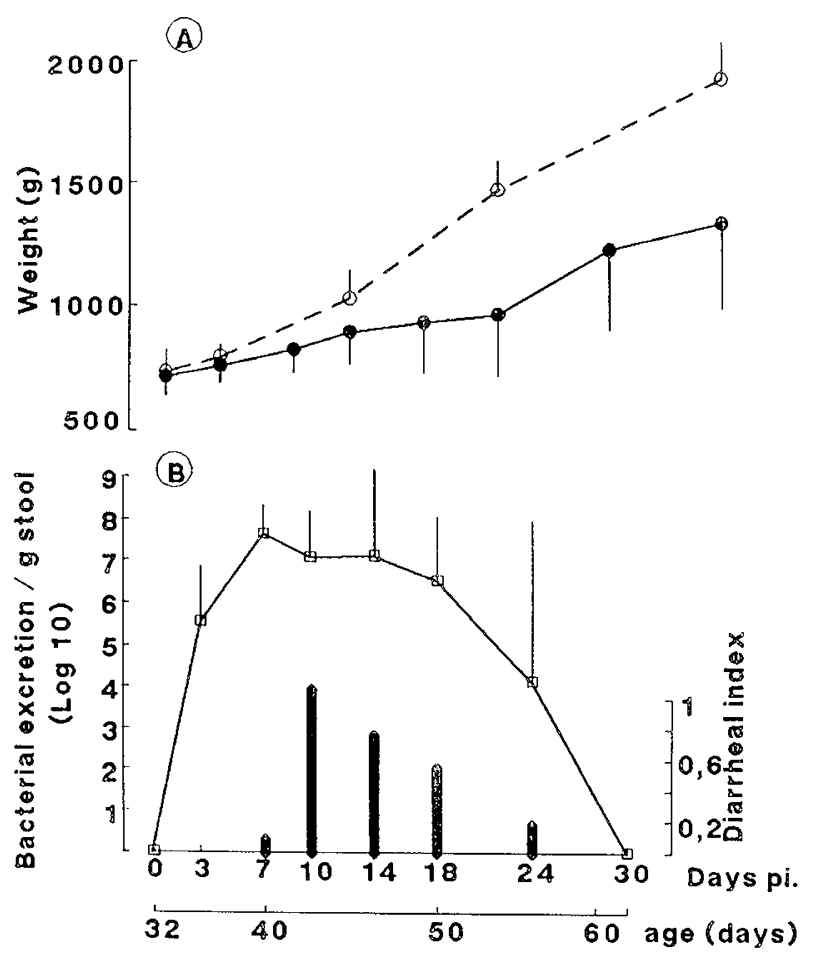

Fig. 1. $A$, growth rate in control $(O)$ and infected $(\bullet)$ rabbits (means $\pm \mathrm{SD}$ ). $B$, fecal excretion of RDEC-1 ( $\square$ ) and diarrheal indexes (vertical bars) during the infection. Each point represents mean \pm SD for four to 10 rabbits. Mean diarrheal indexes are reported for each stage of the disease. 
(240 min). Most of the $\beta$-LG was eluted with the native form and only a small fraction $(<10 \%)$ was degraded, which was considered negligible.

Figure 2 indicates that the transport of $\beta$-LG in antigenic form via the minor direct pathway only constituted $3 \%$ of total transport, whereas the major degrading pathway transported the remaining $97 \%$. The rate at which $\beta$-LG appeared in the portal blood remained constant throughout the second half of the

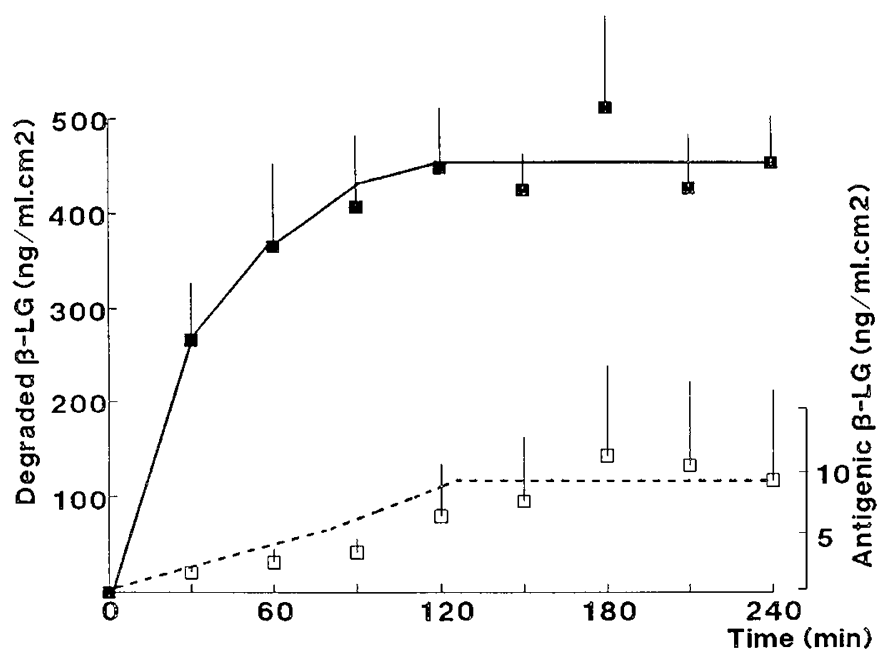

Fig. 2. Kinetics of the appearance of antigenic $(\square)$ and degraded ( $\beta$-LG in portal blood. Results concern five control rabbits aged 50 days (means $\pm \mathrm{SE}$ ).

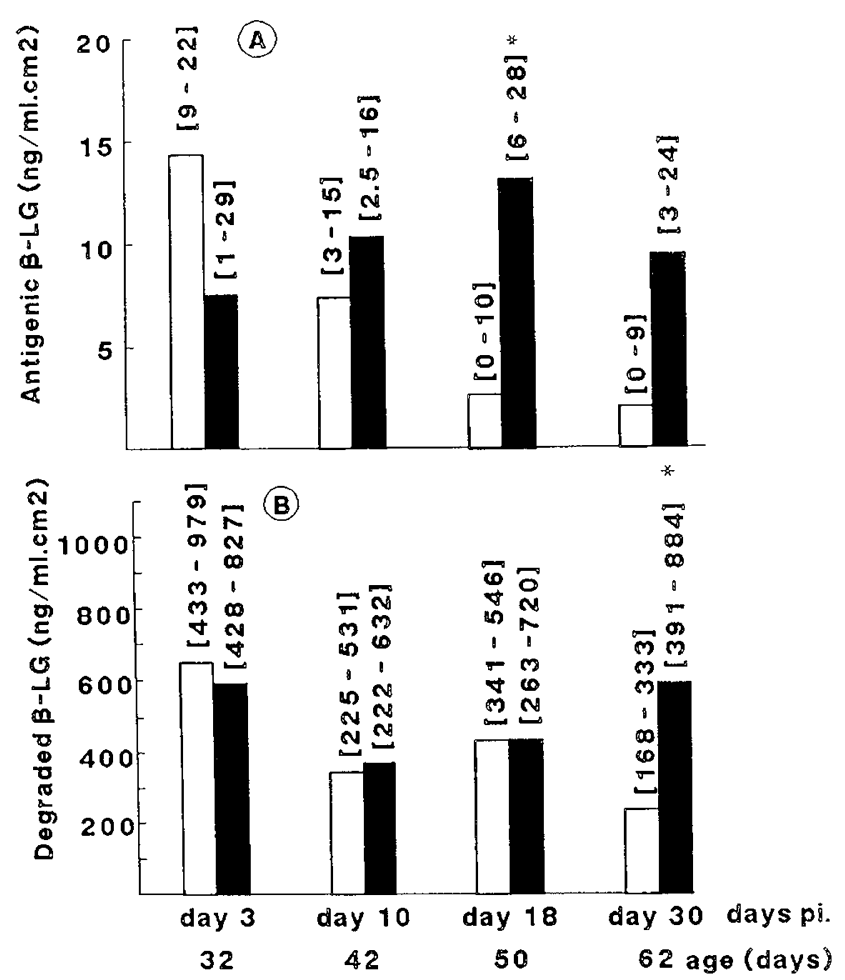

Fig. 3. Antigenic $(A)$ and degraded $(B) \beta$-LG fluxes in control (open bars) and infected (closed bars) rabbits at different stages of the disease. Each bar represents the geometric mean of four to six rabbits and is reported with the $90 \%$ confidence interval in parentheses. $A$, Control rabbits, ANOVA, $\mathrm{F}=3.88, p=0.03$. Infected rabbits, ANOVA, $\mathrm{F}=$ $0.22, p=0.88 .{ }^{*}$ Significantly different from the age-matched control rabbits, Student's t test, $p=0.04$. $B$, control rabbits, ANOVA, $\mathrm{F}=5.45$, $p=0.008$. Infected rabbits, ANOVA, $\mathrm{F}=1.01, p=0.41$. experiment, from 120 to $240 \mathrm{~min}$. Therefore, fluxes are expressed as the means of those measured during the steady-state period.

Evolution of $\beta-L G$ fluxes in RDEC-I-infected and age-matched control rabbits. In control animals, a developmental effect was observed in antigenic $\beta$-LG fluxes (Fig. $3 A$ ). These fluxes gradually decreased from 14.33 to $2.03 \mathrm{ng} / \mathrm{mL} \cdot \mathrm{cm}^{2}$ in rabbits aged from 30 to 60 days. This developmental process probably reflected gut closure to food proteins in the young animals. This developmental effect was also detected in degraded $\beta$-LG fluxes since the latter decreased with age (Fig. $3 B$ ).

RDEC- 1 infection led to a rise in antigenic $\beta$-LG absorption from the acute stage of the disease (day $10 \mathrm{pi}$ ) to the recovery stage (day $30 \mathrm{pi}$ ). This rise abolished the significant reduction of absorption due to gut closure (Fig. $3 A$ ). Differences between experimental and control rabbits were significant at day $18 \mathrm{pi}(p$ $=0.04$. Student's $t$-test). The infection had no effect on absorption of degraded $\beta$-LG (Fig. $3 B$ ) during the early, acute, or late stages of the disease. However, this absorption increased during the recovery phase ( $p=0.03$, Student's $t$ test).

\section{DISCUSSION}

Our results confirm the data obtained in vitro using HRP which suggest that protein absorption proceeds along two functional pathways, a minor pathway allowing the transport of native protein and a major pathway involving lysosomal degradation (5), and that these two pathways can be altered independently $(1,12)$. They also confirm that the epithelial layer of the intestine is the major barrier against the penetration of macromolecular proteins, and show that this barrier may alter during RDEC-1 infection. Various studies have indicated that antigen uptake varies quantitatively and/or qualitatively in gastrointestinal diseases, depending on their etiology (13). In secretory diarrhea (cholera type), there was no modification in HRP transport (3), although in rotavirus infection in infant mice, a selective increase in the permeability of HRP in its native form was observed (1).

In man, epithelial alterations due to gastrointestinal diseases are responsible for the increased passage of food-type antigens (11-13) and perhaps induce allergic reactions in certain individuals $(14,15)$. As bacterial infection is an important cause of gastroenteritis, particularly in children, it seemed to us of interest to ascertain whether protein permeability was modified in an animal model close to human EPEC diarrhea $(16,17)$. The rabbit specific strain RDEC-1 was chosen as it is known to reflect the human disease.

In control rabbits, the 7-fold decrease in antigenic $\beta$-LG fluxes we observed with development confirmed the results of the studies of developing rabbits by Udall et al. (18), who showed the gradual closure of the gastrointestinal tract by measuring in vivo the age-related decrease in its permeability to bovine serum albumin. Here, RDEC-1 infection prevented this closure by increasing the amounts of $\beta$-LG transported by days 18 and 30 pi.

Ultrastructural studies have shown that during RDEC-1 infection, bacteria adhere to the enterocytes, thus causing microvilli effacement and disturbance of the terminal webb and cell cytoskeleton (19). These lesions might modify the enterocyte membrane structure and functions, including the endocytotic mechanism. The existence of a paracellular pathway across the intercellular junctional complex seems improbable because ultrastructural studies indicated the absence of junctional lesions (19). During the present infection, absorption of $\beta$-LG along the degrading pathway did not alter. However, the recovery stage (day $30 \mathrm{pi}$ ) was associated with an increase in degraded $\beta$-LG absorption, which might be attributable to a rapid enterocyte turnover increasing the ratio of immature to mature enterocytes. In this respect, protein absorption by crypt cells was recently found to be double that of villus cells (20), suggesting that immature epithelial cells might transport more proteins than mature cells. 
Taken together, our results indicate that in infant rabbits, intestinal RDEC-1 infection increases mucosal uptake of food antigens in both the antigenic and degraded forms. The immunologic consequences induced by this enhanced absorption will now have to be determined at both the epithelial and systemic levels.

Acknowledgments. The authors thank Dr. E. C. Boedeker for providing the RDEC-1 strain. They also thank M. Dreyfus for revising the manuscript and $F$. Berthet for skillful secretarial assistance.

\section{REFERENCES}

1. Heyman M, Corthier G, Petit A, Meslin JC, Moreau C, Desjeux JF 1987 Intestinal absorption of macromolecules during viral enteritis: an experimental study on rotavirus-infected conventional and germ-free mice. Pediatr Res 22:72-78

2. Keljo DJ, Butler DG, Hamilton JR 1985 Altered jejunal permeability during viral enteritis in the piglet. Gastroenterology 88:998-1004

3. Heyman M, Dumontier AM, Desjeux JF 1986 Intestinal barrier to intact horseradish peroxidase in experimental secretory diarrhea. J Pediatr Gastroenterol Nutr 5:463-466

4. Walker WA 1981 Intestinal transport of macromolecules. In: Johnson LR (ed) Physiology of the Gastrointestinal Tract. Raven Press, New York, pp 1271 1289

5. Heyman M, Ducroc R, Desjeux JF, Morgat JL 1982 Horseradish peroxidase transport across adult rabbit jejunum in vitro. Am J Physiol 242:G558G564

6. Robins-Browne RM 1987 Traditional enteropathogenic Escherichia coli of infantile diarrhea. Rev Infect Dis 9.28-53

7. Cantey JR, Blake RK 1977 Diarrhea due to Escherichia coli in the rabbit: a novel mechanism. J Infect Dis 135:454-462
8. Boedeker EC, Cheney CP 1985 Escherichia coli (strain RDEC-1) diarrhea in the rabbit: an animal model for enteropathogenic $E$. coli (EPEC) infection of human infants. In: Pfeiffer CJ (ed) Animal Models of Intestinal Diseases. CRC Press, Boca Raton, FL, pp 27-40

9. Jentoft N, Dearborn DG 1979 Labeling of proteins by reductive methylation using sodium cyanoborohydride. J Biol Chem 254:4359-4365

10. SAS Institute Inc 1985 Version $G$ Edition. Guide for Personal Computers. SAS Institute Inc, Cary, $\mathrm{NC}$

11. Husby S, Foged N, Host A, Svehag SE 1987 Passage of dietary antigens into the blood of children with celiac disease. Quantification and size distribution of absorbed antigens. Gut 28:1062-1072

12. Heyman M, Boudraa G, Sarrut S, Giraud M, Evans L, Touhami M, Desjeux JF 1984 Macromolecular transport in jejunal mucosa of children with severe malnutrition: a quantitative study. J Pediatr Gastroenterol Nutr 3:357-363

13. Gruskay FL, Cooke RE 1955 The gastrointestinal absorption of unaltered protein in normal infants and in infants recovering from diarrhea. Pediatrics 16:763-769

14. Walker WA 1985 Absorption of proteins and protein fragments in developing intestine: the role of immunologic/allergic reactions. Pediatrics 75:167-171

15. Strobel S 1988 Developmental aspects of food allergy. In: Food Allergy. Nestle Nutrition Workshop Series, Vol 17. Nestlé Ltd, Vevey/Raven Press, Ltd. New York, pp 99-117

16. Rothbaum R, McAdams AJ, Gianella R, Partin JC 1982 A clinicopathologic study of enterocyte adherent Escherichia coli: a cause of protracted diarrhea in infants. 83:441-454

17. Ulshen MH, Rollo JL 1980 Pathogenesis of Escherichia coli gastroenteritis in man-another mechanism. N Engl J Med 303:99-101

18. Udall JN, Pang K, Fritze L, Kleinman R, Walker WA 1981 Development of gastrointestinal mucosal barrier. I. The effect of age on intestinal permeability to macromolecules. Pediatr Res 15:241-244

19. Takeuchi A, Inman LR, O'Hanley PD, Cantey JR, Lushbaugh WB 1978 Scanning and transmission electron microscopic study of Escherichia coli 015 (RDEC-1) enteric infection in rabbits. Infect Immun 19:686-694

20. Heyman M, Crain-Denoyelle AM, Desjeux JF 1989 Protein endocytosis and processing by villus and crypt cells of the mouse small intestine. $J$ Pediatr Gastroenterol Nutr (in press) 